\title{
Protecting Europe's content production from US giants
}

\section{Sally Broughton Micova* ${ }^{\mathrm{a} *}$, Felix Hempel ${ }^{\mathrm{b}}$ and Sabine Jacques ${ }^{\mathrm{c}}$}

${ }^{a}$ School of Politics, Philosophy, Language and Communication, University of East Anglia, Norwich, England; ${ }^{b}$ Law School University of East Anglia, Norwich, England; ${ }^{\circ}$ Law School University of East Anglia, Norwich, England

Email: S.Broughton-Micova@uea.ac.uk

Dr Sally Broughton Micova is a Lecturer in Communications, Policy and Politics at the University of East Anglia School of Politics, Philosophy, Language and Communication

Felix Hempel is a PhD candidate at the University of East Anglia Law School

Dr Sabine Jacques is a Senior Lecturer in IP/IT/Media Law at the University of East Anglia Law School 


\section{Protecting Europe's content production from US giants}

This article investigates and compares the changes to both the Audiovisual Media Services Directive and the Copyright Directive, through which European Union policymakers have sought to protect European content producers, mainly in the face of competition from US-based platforms. Contributing to debates about platform and content regulation, we examine the approaches taken with these two legislative changes and assess the potential for success of the most recent efforts. U1timately, we argue that if revised as proposed the Copyright Directive runs the risk of further adding to the imbalance of power between press publishers and online platforms, and that the level playing field approach taken in the AVSMD revision is more likely to be at least somewhat effective in addressing that imbalance.

Keywords: AVMSD; Copyright Directive, content funding, EU law

\section{Introduction}

As part of its flagship Digital Single Market (DSM) strategy launched in 2015, the European Commission promised to revise two directives that are crucial to Europe's content producers: the Audiovisual Media Services Directive (AVMSD) and the Copyright Directive. The DSM was a direct response to changes in multiple industries arising from the spread of the internet. It aims to facilitate growth in European digital services and networks and to enable consumers and businesses to benefit from the kind of cross-border access the internet can provide. ${ }^{1}$ The rapid spread of largely US-based global online platforms has had severe consequences for Europe's major content producers, the broadcast media and press publishers. Data from across Europe shows advertising revenues increasing for online options and generally decreasing for the broadcasters and press publishers

${ }^{1}$ European Commission, 'Communication from the commission to the European Parliament, the Council, the European Economic and Social Committee and the Committee of the Regions: A Digital Single Market Strategy for Europe' COM (2015) 192 final. 
that have traditionally relied on advertising to fund the production of content. Press circulation figures have plummeted and audiences, particularly younger ones, are shifting away from linear broadcasting. The Commission recognised these issues and sought to address them in its proposals for changes to both the AVMSD and the Copyright Directive, though using very different approaches that we examine in this article. A revised AVMSD was adopted on 2 October 2018 that brought video sharing platforms (VSPs) into its scope, extending to them some of the obligations and rules applicable to audiovisual media services. The version of the Copyright Directive resulting from the Trialogue process would introduce a new right that press publishers can use to try to license their works in the online environment. ${ }^{2}$

The European Union's policy in relation to media has always been constrained, with its competences in this area changing little since the time of the European Economic Community. The EU can only play a supportive role in industrial and cultural policy ${ }^{3}$, so

${ }^{2}$ The Trialogue is the process in which the versionsamended by the European Parliament and the Council of the European Union are agreed with facilitation by the Commission. The talks resulted in a final agreement on 20 February 2019, which at the time of writing still had to be adopted officially in the Parliament. See Council of the European Union 'Interinstitutional File: 2016/0280(COD) of 20 February 2019 Proposal for a Directive of the European Parliament and of the Council on Copyright in the Digital Single Market - Outcome of proceedings' (available at https://data.consilium.europa.eu/doc/document/ST-66372019-INIT/en/pdf), which would update Directive 2001/29/EC of the European Parliament and of the Council of 22 May 2001 on the harmonisation of certain aspects of copyright and related rights in the information society [2001] L 167/10 (hereafter: 'Directive 2001/29/EC').

${ }^{3}$ According to Article 6 of the Treaty for the European Union (TFEU), the Union can 'support, coordinate or supplement the actions of the Member States' in relation to industry and culture, among other things. This is as opposed to other areas in which there is 'shared competence' between the EU and the member states (Article 4), or the EU has 'exclusive competence' (Article 3). 
its policy making powers in relation to media content have been limited to the governance of competition. Nevertheless, since the 1989 Television without Frontiers Directive (TWFD), European policymakers have a long history of engaging in a kind of industrial policy via competition regulation in this area ${ }^{4}$ that has taken a fundamentally liberalising economic approach to media regulation, ${ }^{5}$ and partnered it with specific interventions in the market aimed at protecting Europe's content industries. ${ }^{6}$ As we will demonstrate, the recent changes to the AVMSD draw heavily on this tradition. Copyright remains crucial to how audiovisual content producers monetise and finance content and they have always been vocal about ensuring adequate protections in EU law, but it has not played a significant role in the press industry, which has historically relied very little on trade in the licenses for content. Faced now with a failing press industry, EU policymakers seem to be trying to achieve the aims of a protectionist industrial policy by creating an additional property right in the Copyright Directive, an approach that we will argue is not likely to succeed.

The literature on these two directives and their predecessors has been largely separate, understandably so, with one governing competition in audiovisual production and

${ }^{4}$ Jackie Harrison and Lorna Woods, European broadcasting law and policy (CUP 2007).

${ }^{5}$ Alison Harcourt, The European Union and the regulation of media markets (MUP 2006) presents a detailed account of how this approach came to be and was manifest.

${ }^{6}$ The quotas for European works and independent production that were carried over into the AVMSD, have been described as protectionist industrial policies. See Jackie Harrison and Lorna Woods, 'Television Quotas: protecting European Culture?' (2001) 12 (1) Entertainment Law Review 5; Petros Iosifidis, Jeanette Steemers and Mark Wheeler, European Television Industries (British Film Institute 2005); Sally Broughton Micova, 'Content Quotas: What and Whom are the Protecting' in Karen Donders, Caroline Pauwels and Jan Loisen (eds), Private television in Europe: content, markets and policy (Palgrave 2013). 
distribution markets and the other, mostly, about the enforcement of property rights. Scholarly debates about the TWFD and then AVMSD have focused on the consequences of the liberalisation on national markets, especially for smaller national markets, ${ }^{7}$ the effectiveness of its provisions, ${ }^{8}$ and in the lead up to the most recent revision, the extent to which the Directive was still adequate to the new converged market conditions. ${ }^{9}$ Literature about EU Copyright Law has engaged in debates about harmonization and scope of

${ }^{7}$ For example, Jean-Claude Burgelman and Caroline Pauwels, 'Audiovisual policy and cultural identity in small European states: the challenges of a unified market' (1992) 14 (2) Media, Culture and Society 169; Harcourt (n 5).

${ }^{8}$ One interesting critique of the AVMSD that did connect it to the Copyright issue was that its 'good intentions' toward European content production were doomed to fail because of the Copyright Directive, see Fiona Macmillan, 'Are You Sure/That We Are Awake?: European Media Policy and Copyright' in Karen Donders, Caroline Pauwels and Jan Loisen (eds), The Palgrave Handbook of European Media Policy (Palgrave Macmillan 2014) 382.

${ }^{9}$ Rachael Craufurd-Smith, 'Determining Regulatory Competence for Audiovisual Media Services in the European Union' (2011) 3 (2) Journal of Media Law 263; Michael Wagner, 'Revisiting the Country-of-Origin Principle in the AVMS Directive' (2014) 6 (2) Journal of Media Law 286; Indrek Ibrus and Ulrike Rohn, 'Sharing killed the AVMSD star: the impossibility of European audiovisual media regulation in the era of the sharing economy' (2016) 5 (2) Internet Policy Review 1. 
exclusive rights, ${ }^{10}$ the exhaustive list of exceptions, ${ }^{11}$ and enforceability,${ }^{12}$ most recently in relation to online services. ${ }^{13}$ In the lead-up to this current reform that would introduce a new Directive to update the law for the internet age, academic debates have raised issues of the efficiency of various options, implications for freedom of expression, and the necessity of additional rights. ${ }^{14}$ One of the most debated proposals is for the introduction of

${ }^{10}$ See for example: Adolf Dietz, 'The protection of intellectual property in the information age the draft EU Copyright Directive of November 1997' (1998) 4 IPQ 335; Thomas C. Vinje, 'Harmonising intellectual property laws in the European Union: past, present and future' (1995) 17 (8) EIPR 361.

${ }^{11}$ See for example: André Lucas, Pierre Sirinelli and Alexandra Bensamoun, Les exceptions au droit d'auteur: état des lieux et perspectives dans l'Union européenne (Dalloz 2012); Robert Burrell and Allison Coleman, Copyright Exceptions: The Digital Impact (CUP 2005); Mireille Buydens and Séverine Dussollier, 'Les exceptions au droit d'auteur: évolutions dangereuses' [2001] CCE 10.

${ }^{12}$ See for example: Charles-Henry Massa and Alain Strowel, 'The scope of the proposed IP enforcement directive: torn between the desire to harmonise remedies and the need to combat piracy' (2004) 26 (6) EIPR 244; Stefan Kulk and Frederik Zuiderveen Borgesius, 'Filtering for copyright enforcement in Europe after the Sabam cases' (2012) 34 (11) EIPR 791.

${ }^{13}$ See for example: Paul Joseph, 'copyright Reform: end of a dream?' (2015) 10 (2) JIPLP 73; Sophie Stalla-Bourdillon, Eleonora Rosati, Karmen Turk, Christina Angelopoulos, Aleksandra Kuczerawy, Miquel Peguera and Martin Husovec, 'An academic perspective on the copyright reform' (2017) 33 (1) C.L.S Rev. 3; Benjamin Farrand, "'Towards a modern, more European copyright framework", or, how to rebrand the same old approach?‘ (2019) 41 (2) EIPR 65.

${ }^{14}$ In favour: Thomas Höppner, 'EU copyright reform: the case for a publisher's right' [2018] IPQ 1 Against: Martin Kretschmer et al., 'The European Commission's public consultation on the role of publishers in the copyright value chain: a response by the European Copyright Society'(2016) 38 (10) EIPR 591; Eleonora Rosati, 'Neighbouring Rights for Publishers: are National and (Possible EU) Initiatives Lawful?'(2016) 47 (5) 569; Lionel Bently et al., 'Response to Article 11 of the Proposal for a Directive on Copyright in the Digital Single Market, entitled "Protection of press publications concerning digital uses" 
a press publishers' right, which is intended to tackle directly the loss of revenue experienced by publishers. ${ }^{15}$

In this round of revision undertaken as part of the DSM, both the AVMSD and the Copyright Directive are being used by policymakers to try to deal with the challenges for European content production perceived to be coming from the spread of online platforms. In this paper, we contribute to debates about platform policy and regulation by uniquely examining the two Directives together and analysing the changes as efforts to protect the ability of content producers to monetise content, using the comparison to as-

on behalf of thirty seven professors and leading scholars of Intellectual Property, Information Law and Digital Economy'(Centre for Intellectual Property and Information Law, 2016) < https://www.cipil.law.cam.ac.uk/sites/www.law.cam.ac.uk/files/images/www.cipil.law.cam.ac.uk/documents/ipomodernisingipprofresponsepresspublishers.pdf>; Mireille van Eechoud, 'A publisher's intellectual property right: implications for freedom of expression, author and open content policies'(Openfoum Europe, 2017) pp 18$24<$ http://www.openforumeurope.org/wp-content/uploads/2017/01/OFE-Academic-Paper-Implications-of-publishers-right_FINAL.pdf $>$; Giancarlo Frosio, Christophe Geiger and Oleksandr Bulayenko, 'The introduction of a neighbouring right for press publisher at EU level: the unneeded (and unwanted) reform'(2017) 39(4) EIPR 208; Taina Pihlajarinne and Juha Vesala, 'Proposed right of press publishers: a workable solution?'(2018) 13 (3) Journal of Intellectual Property Law \& Practice 220.

${ }^{15}$ See CREATe, 'Copyright Reform: Open Letter from European Research Centres' (2017) $<$ https://www.create.ac.uk/wp-content/uploads/2017/02/OpenLetter_EU_Copyright_Reform_24_02_2017.pdf>; JRC, 'Online News Aggregation and Neighbouring Rights for News Publishers' (2017)<https://www.asktheeu.org/en/request/4776/response/15356/attach/6/Doc1.pdf>; European Parliament's Policy Department for Citizens' Rights and Constitutional Affairs, 'Strengthening the Position of Press Publishers and Authors and Performers in the Copyright Directive' (JURI Committee, 2017) <http://www.europarl.europa.eu/RegData/etudes/STUD/2017/596810/IPOL_STU(2017)596810_EN.pdf>. 
sess the potential for success in those efforts. Firstly, we describe the challenges to European broadcasters and press publishers arising from the recent developments in the market that have been identified as meriting the policy interventions reflected in the revisions to the Directives. Secondly, we offer an account of how until now the EU has worked within its policy making constraints to try to protect European content producers from perceived threats, mainly from US corporations. We show how these efforts have amounted to harmonization of rules and interventions affecting the capacity and incentives for investment in content production. We then examine the relevant changes to the AVMSD and to the proposals for a press publishers right in the Copyright Directive, elaborating the different approaches. We argue that the levelling of the playing field approach taken in the AVMSD revision is more likely to at least slightly address the challenges facing European content producers than the approach in the planned Copyright Directive, which is more likely to add further to the imbalance of power between press publishers and online platforms.

\section{The impact of online platforms on 'traditional' content producers}

The spread of online platforms has caused a number of issues for 'traditional media,'16 most of which they claim make it more challenging for them to generate revenues and thus, fund new original content. ${ }^{17}$ Competition is intensifying following an explosion of

\footnotetext{
${ }^{16} \mathrm{By}$ this term, we mean press publishers (newspapers and magazines), linear audiovisual media services (television), and radio.

${ }^{17}$ See various responses to the European Commission's consultation on the regulatory environment for platforms, online intermediaries, data and cloud computing and the collaborative environment well as the European Commission's consultation of the role of publishers in the copyright value chain and on the "panorama exception", for example: European Publishers Council (EPC), 'Public Consultation on the role of publishers in the Copyright
} 
digital content and platforms, on-going globalisation and market fragmentation, and constantly changing media consumer preferences and habits. ${ }^{18}$ This led some scholars to argue that the internet has the power to 'cannibalise' traditional offline media. ${ }^{19}$ Press publishers across the EU have experienced threats to their financial sustainability due to a decline in their income from advertising and circulation. Advertising-dependent broadcast television services have had to rethink their main revenue drivers to deal with the increased competition for viewer time and advertiser spending. Advertising-dependent online platforms compete with broadcasters and press publishers for advertising, and often serve as important intermediaries between these traditional content producers and much of their audience due to their function as aggregators or sharing services.

\section{Linear audiovisual media services (television)}

The audiovisual landscape is changing at a rapid pace, with long-lasting consequences on the traditional media ecosystem, a large part of which is dependent on advertising income

value chain and on the 'panorama exception' (European Commission Report and Studies, 2016) <http://ec.europa.eu/information_society/newsroom/image/document/2017-38/organisations_registered_in_the_transparency_register_A05B8047-BE72-2BA6838F586F7C0D4A85_47162.zip>; The European association of television and radio sales houses (egta), 'Answer to the public consultation on online platforms, cloud \& data, liability of intermediaries, collaborative economy' (European Commission Report and Studies, 2016) <http://ec.europa.eu/information_society/newsroom/image/document/20167/egta_13918.pdf $>$.

${ }^{18}$ Tom Evens, 'Media economics and transformation in a digital Europe' in Leen d'Haenens et. al (eds), Comparative Media Policy, Regulation and Governance in Europe. Unpacking the Policy Cycle (Intellect 2018) 41.

${ }^{19}$ For an overview of those scholars, see: Jiyoung Cha and Sylvia M. Chan-Olmsted, 'Substitutability between Online Video Platforms and Television' (2012) 89 (2) Journalism \& Mass Communication Quarterly 261. 
to finance the production of content. ${ }^{20}$ Viewing habits have changed significantly, with younger audiences in particular watching more online than offline content in some markets, and more often watching content on portable devices. Viewing time is a crucial metric in the audiovisual sector, as the number of people consuming a media service is of particular significance for its income. ${ }^{21}$ It is taken into consideration by the advertisers when deciding how to place their commercial communication around any given programme and determines what they are willing to pay for it. ${ }^{22} \mathrm{With}$ the spread of connected TVs, addressable and interactive advertising for television is developing in most European markets, yet it still remains very difficult to track a consumer's reaction to most broadcast advertising. ${ }^{23}$ As a result, advertisers pay on the basis of consumers' anticipated exposure to the ad rather than their actions as a result of seeing the ads. ${ }^{24}$ Therefore, a

${ }^{20}$ European Audiovisual Observatory, 'Commercial communications in the AVMSD revision' (Council of Europe, 2017), p $5<$ https://rm.coe.int/168078348c $>$.

${ }^{21}$ However, audience falls do not always translate into declines in revenue, as audience is only one of three key variables (reach, volume, price) feeding into advertising revenue.

${ }^{22}$ Mario La Torre, The Economics of the Audiovisual Industry: Financing TV, Film and Web (Palgrave 2014) 46.

${ }^{23}$ In the literature, this has been put forward as one of the main weaknesses of television advertising. See for example: Chris Hackley, Advertising and Promotion (SAGE 2017) 192, 193. See also Dirk Bergemann and Alessandro Bonatti, 'Targeting in advertising markets: implications for offline versus online media' (2011) 42 (3) Journal of Economics 417, 418 and Wenjuan Ma et al., 'Online Advertising' in Robin Mansell et al. (eds), The International Encyclopedia of Digital Communication and Society (John Wiley \& Sons 2015) 3. Nevertheless, there is qualitative research available that gives evidence to the effects of television advertising more broadly. See for example: Thinkbox, 'Profit Ability: the business case for advertising research charts' (November 2017) <https://www.thinkbox.tv/Research/Nickable-Charts/Thinkbox-research-charts/Profit-Ability-the-business-case-for-advertising?download $=1>$.

${ }^{24}$ James Ratliff and Daniel Rubinfeld, 'Online Advertising: Defining Relevant Markets' (2010) 6 (3) Journal of Competition Law and Economics 679. 
decreased audience has a negative impact on advertising revenues for the traditional broadcast media.

Across Europe, linear TV content still accounts for a major share of average daily viewing time when looking at the whole population, ${ }^{25}$ but this is declining and new types of content, and new players, including video on demand (VOD) and VSPs, are now wellestablished. ${ }^{26}$ There has been a drastic change of dynamics for younger audiences, with online video consumption increasing and linear TV consumption dropping ${ }^{27}$. As users watch more video content online, advertisers are allocating higher proportions of their

${ }^{25}$ In 2017, Broadcast TV made up 71\% of people's total TV and audiovisual daily viewing; the remaining 29\% was non-broadcast content such as YouTube and subscription on-demand services such as Netflix and Amazon Prime Video.

${ }^{26}$ In the UK television viewing is declining significantly. European Commission, 'Proposal for a Directive of the European Parliament and of the Council amending Directive 2010/13/EU on the coordination of certain provisions laid down by law, regulation or administrative action in Member States concerning the provision of audiovisual media services (Audiovisual Media Services Directive) in view of changing market realities' (Eur-Lex, 25 May 2016), Recital $1<\mathrm{http}$ //eur-lex.europa.eu/legal-content/EN/TXT/PDF/?uri=CELEX:52016PC0287\&from=EN> (hereafter 'AVMSD Proposal'). In France and Germany slightly less drastically, where it dropped by 4 minutes a day between 2011 and 2016. European Audiovisual Observatory, 'Yearbook 2017/2018 Key Trends', p 44 (Council of Europe, 2018) <https://rm.coe.int/yearbook-keytrends2017-2018-en/16807b567e> and Kommission zur Ermittlung der Konzentration im Medienbereich, 'Fernsehnutzung' $(K E K, 2018)<$ https://www.kek-online.de/medienkonzentration/mediennutzung/fernsehnutzung/>.

${ }^{27}$ For UK data see Ofcom, 'Media Nations: UK', p 4, 20 (18 July 2018) $<$ https://www.ofcom.org.uk/_data/assets/pdf_file/0014/116006/media-nations-2018uk.pdf $>$ and for the German example see Kommission zur Ermittlung der Konzentration im Medienbereich, ' Internetnutzung $(K E K, 2018)<$ https://www.kekonline.de/medienkonzentration/mediennutzung/internetnutzung/>. 
budgets to such channels. ${ }^{28}$ In Europe, online video advertising income is expected to have grown by $720 \%$ between 2010 and the end of $2018,{ }^{29}$ with a market share of almost $60 \%$ in the EU-5 for Facebook and YouTube. ${ }^{30}$ In contrast, the size of the EU television advertising market decreased by $8 \%$ between 2008 -before the economic downturn- and $2016,{ }^{31}$ despite the stabilisation of the market to a compound annual growth rate (CAGR) of $2.2 \%$ between 2011 and $2016 .{ }^{32}$ The internet has overtaken TV as the top advertising medium, as online advertising in total grew with a CAGR of $17.8 \% .{ }^{33}$ The ability to target very specifically, availability of measurement data, and technological tools to ease buying online ad inventory seem to make it an attractive option for those deciding where to spend their advertising budgets.

Finally, some online platforms also compete with traditional content producers for on-screen talent, programme producers, writers and other production inputs, ${ }^{34}$ but with much larger budgets at their disposal. VOD services are now provided by traditional

${ }^{28}$ David Abecassis et al., 'Convergence of TV and Digital Platforms: Increased Innovation and Competition for Advertisers Budgets' (SSRN, 2017), p $9<$ https://papers.ssrn.com/sol3/papers.cfm?abstract_id $=3092181>$.

${ }^{29}$ Christian Grece, 'The online advertising market in the EU - Update 2015 and focus on programmatic advertising' (European Audiovisual Observatory, 2016) p $40<\mathrm{https}$ ://ec.europa.eu/newsroom/document.cfm?doc_id=43866>.

${ }^{30}$ ibid, p 4.

${ }^{31}$ European Audiovisual Observatory, 'Yearbook 2017/2018 - Key Trends' (n 26) 48.

${ }^{32}$ Christian Grece, 'The online advertising market in the EU - Update 2017' (European Audiovisual Observatory, 2016), p $7<\mathrm{https}$ ://rm.coe.int/the-eu-online-advertising-market-update-2017/168078f2b3>.

${ }^{33}$ ibid.

${ }^{34}$ Joylon Baker et al., 'Television's business model - Fit for a digital world' (Deloitte, 2014), p 5 $<$ https://www2.deloitte.com/content/dam/Deloitte/au/Documents/technology-media-telecommunications/deloitte-au-tmt-televisions-business-model-031014.pdf $>$. 
television channels and telecom operators, directly from some film producers and distributors, by content aggregators, video sharing platforms and even from audiovisual archives and public support funds; $;{ }^{35}$ however, it is subscription-based services such as Netflix that are experiencing rapid expansion. ${ }^{36}$ The key reason for this rise in subscriptions was the access to original and exclusive content. ${ }^{37}$ While global players like Netflix and Amazon are driving up the costs of production with their large budget projects, traditional audiovisual content producers have seen reduced budgets, particularly public service media. ${ }^{38}$ Still, investment of VOD providers in original programmes for the production and promotion of EU works remains minimal compared to the main TV groups on an EU level. ${ }^{39}$ Public service broadcaster (PSBs), many of which have mixed funding systems that include advertising, originated $73 \%$ of TV fiction and $44 \%$ of TV fiction hours produced each year in Europe, but the future of this investment is uncertain as, except in Germany,

${ }^{35}$ See Christian Grece et al., 'The development of the European Market for on-demand audiovisual services' (European Audiovisual Observatory, 2015) <http://ec.europa.eu/newsroom/dae/document.cfm?action=display\&doc_id=9273>.

${ }^{36}$ ibid, 4.

${ }^{37}$ Ofcom 'Media Nations UK' (n 27) 15.

${ }^{38}$ According to Ofcom, 'Communications Market Report 2018' (Ofcom, 2018), p 34 $<$ https://www.ofcom.org.uk/_data/assets/pdf_file/0022/117256/CMR-2018-narrative-report.pdf $>$ spending by BBC ITV, Channel 4 and Channel 5 on new UK-made TV programmes fell to a 20-year low in 2017. And there were there were significant drops in investment in original programmes by broadcasters in Italy (-16\%), Spain (-25\%), Ireland (17\%) and Portugal (-26\%) during the period 2009-2013, see Deirdre Kevin, 'Investments in original content by audiovisual services', p 11 (European Audiovisual Observatory, 2015) <https://rm.coe.int/16807835ca> .

${ }^{39}$ In 2013, the main TV groups in 15 countries invested EUR 15.6 billion (i.e. $24 \%$ of their total revenues) in these original works. In contrast, VOD providers invested EUR 10 million (i.e. less than $1 \%$ of their total revenues. For further information see: Kevin (n 38). 
PSB revenues have been hard hit across Europe. ${ }^{40}$ Investment in original content production by some larger online VOD services does not seem to be compensating for the reduced capacity of those that have been the engines of European content production.

\section{Press publishers}

Since the beginning of the spread of online platforms, press publishers have been experiencing significant declines in revenues and circulation. Research shows that fewer and fewer people read print newspapers, and young people who once could be expected to become newspaper readers as they matured, long ago stopped making that transition. ${ }^{41}$ This has led to a significant change in the funding for newspaper content, which traditionally heavily relied on advertising revenues alongside paid subscriptions. Advertising budgets have migrated away from newspapers and magazines to online display, search, and classified formats, due to falling print circulation levels and the relatively high costs of placing print advertisements. ${ }^{42}$ Platforms offer cheaper, often free, alternatives to the classified ads, which used to be a source of reliable revenues for newspaper publishers, and provide cheaper and more targeted alternatives to display advertising in print. At the same time, platforms compete directly with print media, including their online versions for audience attention. News aggregators, search platforms and social media often also serve as an intermediary between press publishers and their audiences as content produced by the publishers is accessed via the platforms. While this sometimes helps the content reach much wider audiences than it would have otherwise, publishers cannot

\footnotetext{
${ }^{40}$ European Audiovisual Observatory, 'Yearbook 2017/2018 - Key Trends' (n 26) 64.

${ }^{41}$ Elizabeth Bird, 'The future of journalism in the digital environment' (2009) 10 (3) Journalism 293.

${ }^{42}$ Ofcom, 'Communications Market Report' (n 38) 45.
} 
monetise that additional reach unless audiences click to their own ad-supported website.

In the EU, the market share of newspapers as an advertising medium was $14.3 \%$ in 2016, down from 23\% in 2011 and 6.6\% in magazines, down from $11 \%$ in 2011 with varying but clear downturns in every national market across Europe. ${ }^{43}$ Press publisher's efforts to open up new digital revenue streams (e-editions, paywalls, reader contributions, programmatic advertising, and digital marketing services), have not come close to recouping the revenues lost from changes to traditional print consumption. ${ }^{44}$ Even when users engage with news brands online, the yields for publishers are much lower than in analogue print. ${ }^{45}$ Increasingly, users are primarily accessing news on platforms like Facebook, ${ }^{46}$ which, along with a plethora of advertising-supported websites not connected to press publishers, compete with the traditional producers of news content for advertising

\footnotetext{
${ }^{43}$ European Audiovisual Observatory, 'Yearbook 2017/2018 - Key Trends' (n 26) 48. For specific data from France seeConseil Superieur De L'Audiovisuel, 'Media et Publicite en ligne' (European Platform of Regulatory Authorities, July 2018), p 3 $<$ https://www.csa.fr/content/download/252403/690290/version/7/file/CSA_Etude\%20Médias\%20et\%20Publicités.pdf $>$ and for the UK see Mediatique, 'Department for Digital, Culture, Media \& Sport - Overview of recent dynamics in the UK press market' (DCMS, 2018), p 43 <https://assets.publishing.service.gov.uk/government/uploads/system/uploads/attachment_data/file/720400/180621_Mediatique_-_Overview_of_recent_dynamics_in_the_UK_press_market_-_Report_for_DCMS.pdf>.

${ }^{44}$ ibid.

${ }^{45}$ Mediatique (n 43) 37. At the aggregate level, one print reader is worth approximately eight digital users, see Deloitte, 'UK News Media: an engine of original news content and democracy' (News Media UK, 2016) <http://www.newsmediauk.org/write/MediaUploads/In\%20the\%20Spotlight/NMA\%20Economic\%20Report/Final_Report_News_Media_Economic_Impact_Study.pdf $>$

${ }^{46}$ European Audiovisual Observatory, 'Commercial communications in the AVMSD revision' (n 20) 5 .
} 
spend. It has been argued therefore that the fact that the many online platforms are advertising funded media but do not produce content themselves poses a serious threat to adfunded journalistic media. ${ }^{47}$

Much of the news that is being accessed on online platforms is created by press publishers and other traditional news media, with online platforms serving as intermediaries by aggregating and producing excerpts or allowing people to share links, often with images and headlines or excerpts. These platforms often satisfy readers' need for information without readers getting to the webpage of the publisher, ${ }^{48}$ without, therefore, the publisher being able to monetise the attention of those readers. A Reuters Institute experiment tracking more than 2,000 respondents in the UK, found that while most readers could remember the path through which they found a news story (Facebook, Google, etc.), less than half could recall the name of the news brand that had created that content when accessing it from search (37\%) and social media (47\%), ${ }^{49}$ and in several countries well over half used the platform for news. ${ }^{50}$ Significant numbers of people are therefore using platforms like Facebook to access news and may not even know the source that created the news or contribute to the monetisation of that content for the publisher.

\footnotetext{
${ }^{47}$ For an overview of these issues including examples see: Gabriele Siegert, 'From "the end of advertising as we know it" to "beyond content"? Changes in advertising and the impact on journalistic media' in Heinz-Werner Nienstedt et al. (eds), Journalism and media convergence (de Gruyter 2013) 34.

${ }^{48}$ For further information on the sources of news consumption, see for example: Ofcom, 'News consumption in the UK: 2018' (2018) <https://www.ofcom.org.uk/_data/assets/pdf_file/0024/116529/news-consumption-2018.pdf $>$.

${ }^{49}$ Nic Newman and others, Reuters Institute Digital News Report 2017 (Reuters Institute for the Study of Journalism 2017) 10.

${ }^{50}$ ibid. Romania $69 \%$ and Greece $62 \%$. The UK and Germany had the lowest figures for the use of Facebook for news.
} 


\section{The threats}

The prediction of the early 2000s that "television is dead" has not yet happened, but the Commission rightly identified significant challenges to Europe's broadcasters, and an urgency to these challenges. The evidence shows that attention is moving away from traditional producers of content, their revenues are being affected by competition for advertising spend from online platforms offering audiovisual content. The first challenge comes from subscription VOD services such as Netflix that are gaining ever-larger shares of audience attention and driving up prices for content production, but not yet investing equivalently in original European content. The second major challenge comes from advertising dependent sharing platforms such as YouTube, which competes for both viewer attention and advertising budgets. Press publishers have suffered the most from the spread of online platforms. Their offline readerships have declined drastically, while the revenues they are generating from their own online activities are far from compensating for that loss. They face competition for advertising budgets and the also face the intermediary challenge, which is essentially that their ability to monetise their content is being affected by the fact that it is increasingly being consumed and shared via online platforms. Arguments that what is at stake is the maintenance of European culture and the future provision of the news content crucial to Europe's democratic processes have found sympathy among many EU level policymakers.

\section{EU's history of protectionism}

It is not new for European policymakers to be sympathetic to the plight of content producers. The EU's liberalising economic approach has been tempered by a heavy dose of protectionism against perceived threats to European content production, rooted in assumptions about the benefits of both a common, competitive market and of protectionist 
measures that have long featured in the national policy of many member states.

\section{Liberalising for European Giants}

Broadcasting was defined as an economic activity, as opposed to a public good, by the landmark 1974 case Sacchi v Italy, ${ }^{51}$ when a cable operator sued against the monopoly of the Italian public service broadcaster. ${ }^{52}$ The determination that broadcasting would be regulated by competition rules, and not treated as a cultural institution, paved the way for liberalisation in television broadcasting. The Television without Frontiers Directive (TWFD) that was adopted in 1989 required the removal of barriers to cross border transmission of television services. ${ }^{53}$ Many PSBs found their positions weakened by the increased competition; however, this liberalisation was intended to boost rather than undermine European content production.

In the policy processes that led up to the TWFD, the rapid spread of American content was perceived to be a threat to the European content production sector, and therefore to European culture, and one of the aims of the Directive was to help European producers and European content be more competitive. ${ }^{54}$ At that time, most broadcast content

\footnotetext{
${ }^{51}$ Case C-155/73 Sacchi [1974] ECR 409.
}

${ }^{52}$ For full discussion of implications of this case see Eric Barendt and Leslie Hitchens, Media Law: Cases and Materials (Pearsons Education Limited 2001) 168.

${ }^{53}$ For example, even though Austria did not end its PSB monopoly in television until the adoption of a law on commercial television in 2001, foreign channels, particularly ones from Germany already had captured significant audiences, see Thomas Steinmaurer, 'Diversity through delay?: the Austrian case' (2009) 71 (1-2) International Communication Gazette 77.

${ }^{54}$ See discussion in Harrison and Woods (n 4); Andrea Esser, 'Trends in Programming: Commericalization, Transnationalization, Convergence' in Alec Charles (ed), Media in the enlarged Europe: politics, policy and industry (Intellect 2009) 23; Jeremy Tunstall and David Machin, The Anglo-American Media Connection (OUP 1999). 
was produced or commissioned by PSBs, and even many of them were showing large amounts of content produced in the US. ${ }^{55}$ The TWFD was intended to give European television providers access to larger audiences in hopes it would give them a benefit of scale somewhat comparable to services in the US. This primarily applied to commercial services, but also to PSBs with dual funding that relied partially on advertising. It was also intended to enable cross-border investment in commercial television services and pan-European distribution of content.

\section{Pan-European quotas and common advertising standards}

The TWFD's market maximising approach was coupled with the very protectionist measure of imposing quotas for European works and independent production aimed at ensuring a market for the production industries. ${ }^{56}$ Since the 1989 Directive, television stations in Europe have had to ensure that at least $50 \%$ of their broadcast time was made up of European works, and $10 \%$ had to be dedicated to independent production. ${ }^{57}$ As they often run parallel to similar national measures aimed at protecting national industries and culture, European works quotas are generally met by domestic content with limited or no market outside its country of origin. ${ }^{58}$ With the 2007 AVMSD, VOD services were encouraged to promote European works in their catalogues, and member states were

\footnotetext{
${ }^{55}$ David Hutchinson, 'The European Community and Audio-visual Culture' [1993] Canadian Journal of Communications 437.

${ }^{56}$ Harrison and Woods (n 6); for more on quotas as economic or commercial protectionism see also: Harrison and Woods (n 4) and Lesley Hitchens, Broadcasting Pluralism and Diversity (Hart Publishing 2006).

${ }^{57}$ This $10 \%$ could be out of production budgets rather than broadcast time.

${ }^{58}$ Where the European quota is higher than domestic ones, they may further help ensure national language(s) are on air and they may contribute to culturally relevant production in states in which regulators have further defined qualifying content. Broughton Micova (n 6).
} 
charged with monitoring. The Directive sets out common conditions on the nature of advertising, prohibiting medicinal products and subliminal messaging and requiring respect for human dignity and the protection of minors. ${ }^{59}$ This feature of the AVMSD can be seen as an attempt to level the playing field among services.

\section{The Use of State aid}

The use of state aid within the common market is allowed for the development of certain economic activities and areas as it 'does not adversely affect trading conditions to an extent contrary to the common interest' ${ }^{60}$ State aid to public service broadcasting is specifically allowed under the Amsterdam Protocol, as long as it has been conferred a public service remit by the member state, and does not affect trading conditions and competition to an extent beyond the common interest. ${ }^{61}$ With two Communications, 2001 and 2009, ${ }^{62}$ and decisions on individual cases, the Commission has gradually constrained the use of state aid for PSB and moved towards requiring an ex ante test for public value and market impact for new services and ever more specific definitions of remit and services. ${ }^{63}$ At the

${ }^{59}$ Directive 2007/65/EC of the European Parliament and of the Council of 11 December 2007 amending Council Directive 89/552/EEC on the coordination of certain provisions laid down by law, regulation or administrative action in Member States concerning the pursuit of television broadcasting activities [2007] L332/27, art 9 (hereafter: 'AVMSD 2007').

${ }^{60}$ TFEU Article 107(3)(c), formerly of Article 87 of the European Community Treaty.

${ }^{61}$ Treaty of Amsterdam amending the Treaty on European Union, the Treaties establishing the European Communities and certain related acts [1997] OJ C 340.

${ }^{62}$ European Commission, 'Communication from the Commission on the application of State aid rules to public service broadcasting' [2001] OJ C 320/04); European Commission, 'Communication from the Commission on the application of State aid rules to public service broadcasting' [2009] OJ C 257/01.

${ }^{63}$ For example, see European Commission, 'Decision of 28 October 2009 concerning state funding for Austrian public broadcaster' [2009] E2/2008, which was decided shortly after the 
same time, the case record indicates that the Commission rarely raises objections to tax breaks or direct funding for content production outside of the PSB systems. Subsidies for the production of TV and radio programmes for broadcast on commercial services rather than PSB have been regularly supported, for example in France ${ }^{64}$ and Denmark ${ }^{65}$ several $^{2}$ times, and also recently in Croatia. ${ }^{66}$

State subsidies to support press publishers are also very common in Europe and often also constitute state aid. With a few exceptions, the Commission has been very accepting of national funds to support press publishers in the production of content, and

2009 Communication place extensive requirements on Austria to further define and limit the remit of its ORF, with specific conditions on its activities related to sports coverage and online services and required a revision of supervision and additional rules on market behaviour. In a later example, it required Belgian authorities to amend the regulatory framework for RTBF to install a clear distinction between its PSB and commercial activities and ex ante tests for new services. A more extensive discussion of Commission decision before and after the 2009 Communication can be found in Karan Donders, 'State Aid to Public Service Media' (2015) 14 (1) European State Aid Law Quarterly 68.

${ }^{64}$ European Commission, 'Aides financières automatiques à la production et à la préparation des oeuvres cinématographiques de longue durée' [2017] SA.48699, which continued support in cases European Commission, 'Extension of French film support schemes' [2011] SA.33370 (for the audiovisual support scheme for period 2014-2017); European Commission, 'Aides financières automatiques à la production et à la préparation des œuvres audiovisuelles - documentaire de création et fiction' [2017] SA.48907 (for documentaries); European Commission, 'Régimes d'aide au cinéma et à l'audiovisuel' [2006] NN84/2004.

${ }^{65}$ European Commission, 'Scheme for the production and broadcasting of Danish TV drama and TV documentary programmes (prolongation of State aid N360/2007, N599/2009 and SA.32479)' [2013] SA.36761, which repeated the support given also in cases N360/2007, N599/2009, SA.32479 (2011) for the Danish 'Public Service Pool' for the production of TV drama and documentaries for broadcast by non-PSB services.

${ }^{66}$ European Commission, 'Decision on subsidizing the production and broadcasting of audiovisual and/or radio programmes for radio and TV broadcasters' [2013] SA.35513. 
not just for printed press. For example, the Danish press support scheme was allowed to provide state aid of approximately $€ 52$ million between 2014 and 2019 to press publishers to produce content that could be distributed on the platform of their choice. ${ }^{67}$ Support for local minority language print and online publishers is sometimes not even considered to constitute state aid because they have such a local impact. ${ }^{68}$ In cases where there could be implications for publishers from a neighbouring 'kin state' to a national minority the Commission still did not raise objections. ${ }^{69}$ It has also raised no objections to grants directly to publishers in order to help them overhaul their online offering ${ }^{70}$ which could be considered in competition with online services from anywhere. The Commission has consistently allowed state aid in the form of sustained financial support to press publishers and ad hoc assistance to help struggling publishers modernize and meet the challenges of the current media market.

\section{Protecting against the threats from across the Atlantic}

Since the late 1980s, European media policymakers have tread carefully within an overall

${ }^{67}$ European Commission, 'Production and innovation aid to written media' [2013] SA.36366.

${ }^{68}$ For example, in cases European Commission, 'Aid to support the Valencian language in the press [2016] SA. 45512 and European Commission, 'Promotion of the Basque language in digital news media' [2017] SA. 47448 dealing with Valencian and Basque language publishers in Spain the commission determined the assistance did not constitute aid.

${ }^{69}$ For example, in cases European Commission, 'Individual state aid to Madach-Posonium, Lilium Aurum, Petit Press' [2013] SA.35814, SA.35815 and SA.35816, the Commission allowed the Slovak government to provide direct support to private publishers to produce newspapers, magazines and online content in Hungarian language.

${ }^{70}$ The Greek government was allowed to make temporary grants to 3 private publishers specifically to improve their offerings online with the aim of sustainability. European Commission Decision, 'Restructuring aid to Makedoniki and Ekdotiki' [2012] SA.33741 and European Commission Decision, 'Restructuring aid to Kalofolias' [2010] N672/2008. 
liberal market paradigm to attempt to protect European content production, particularly commercial producers of content, in the face of threats from across the Atlantic. The TWFD was drafted against the backdrop of the spread of American made television programmes and films. It was intended to enable commercial broadcasting to grow within a wider European market with common standards making a level playing field, and to encourage investment in European content through quotas. When the AVMSD replaced it, changes were made to account for technological change, but the overall approach remained the same. State aid has been widely allowed to support content production in both broadcasting and press publishing, including national level schemes to help press publishers adapt and even bailouts to specific press publishers. These tactics used so far have all been ones that attempt to shape the conditions of competition, whether it was by affecting the rules by which competing services must play, in the direction of equalising them, or by weighing in on one side with quotas or state aid to affect investment in European content.

\section{The latest attempts to save European content production}

The 2015 DSM Strategy initiated revisions to the AVMSD and the Copyright Directive, as well as a review of the role of online platforms, as part of its overall aim to create enabling conditions for European digital networks and services. Once again, European policymakers had identified a threat to European content producers, this time in the form of online platforms, largely global companies based in the US. In this section, we elaborate how elements of the revision to the AVMSD and the introduction of a press publisher's right in the Copyright Directive are attempts to redress the imbalances between the online platforms and Europe's audiovisual media and press publishers. We identify 
the differences in the approaches and likely consequences for the policies' potential effectiveness.

\section{An AVMSD for a digital age}

The 2018 revision to the AVMSD introduced a number of changes, including clarity on jurisdiction and conditions for derogation from the country of origin principle and the establishment of the European Regulators Group (ERGA), along with criteria for independent regulators. Here we focus on those provisions of the revised Directive that relate to the funding of content. The first set of provisions are aimed at ensuring investment in European works, whereas the other set establishes common standards, mainly in consumer protection. Essentially the first addresses the Netflix challenge ${ }^{71}$ and the other the YouTube challenge, both which we described above. The provisions are aimed at incentivising investment in European content production and levelling the playing field on which these newer services compete with European audiovisual media services for advertising. ${ }^{72}$

The Commission already in 2013 pointed out that without the territorial restrictions, online audiovisual media services should be able to address all the EU's internet users, but that it was US services that were successfully reaching this fragmented

\footnotetext{
${ }^{71}$ For an elaboration of the Netflix challenge with the example of the case of its servicing the French market from Luxembourg, see Wagner (n 9).

${ }^{72}$ The provisions related to advertising are also intended to extend protections for audiences, especially minors, but this is outside the scope of this paper. The levelling of the playing field for competing services was expressed clearly in the preparatory documents, the preamble and in the statements of policymakers.
} 
market. ${ }^{73}$ In May 2015 it issued a proposal for revising the AVMSD that referred to calls from broadcasters for a more level playing field and to content producers for stronger obligations on European works. The Commission proposed a 20\% European works requirement for VOD catalogues as part of its "levelling up" of the rules across all services. $^{74}$ It also proposed that member states be allowed to impose financial contributions to the production of European works not just on VOD services in their jurisdiction, but also on those targeting their citizens, giving a green light to laws underway in France and Germany imposing such levies.

The final version adopted by the European Parliament in October 2018 raises the requirement for European works in VOD catalogues to $30 \% .{ }^{75}$ It also changed the Commission's original wording on the imposition of financial contributions to apply to "media service providers" more generally and not just VOD providers. ${ }^{76}$ This is not a small

${ }^{73}$ European Commission, ‘Green Paper: Preparing for a Fully Converged Audiovisual World: Growth, Creation and Values' COM (2013) 231 final, p 5.

${ }^{74}$ In the explanatory note accompanying the proposal the Commission stated it would amount to a levelling up of the rules on VOD and VSP services to accompany a relaxation of rules for linear audiovisual media services. See AVMSD Proposal (n 26) 10.

${ }^{75}$ Gilles Fontaine and Christian Grece, 'Origin of films and TV content in VOD catalogues in the EU \& Visibility of films on VOD services' (EAO, 2016) $<$ https://rm.coe.int/1680783582>, found Netflix to be the only pan-European subscription VOD provider with $19 \%$ of its film catalogue made up of European films and $32 \%$ of its TV programme catalogue made up of European works, though there was variation on these figures across the 28 countries in which it did business.

${ }^{76}$ European Parliament, 'European Parliament legislative resolution of 2 October 2018 on the proposal for a directive of the European Parliament and of the Council amending Directive 2010/13/EU on the coordination of certain provisions laid down by law, regulation or administrative action in Member States concerning the provision of audiovisual media services in view of changing market realities (COM(2016)0287 - C8-0193/2016 - 
change. It may ostensibly seem fairer, as it would apply to linear and on-demand services, however providers of linear audiovisual media services are still overwhelmingly the biggest investors in the production of European content. ${ }^{77}$ If member states put additional levies on such services it could create further imbalance, as some broadcasters may have to contribute some of their already tight budgets to film funds or similar schemes that may not translate back into filling transmission time on their own services against which advertising can be sold. It also gives room for governments to abuse the imposition of such levies for political purposes. Though it largely reflects the existing situation, the quota on catalogues may contribute in a small way towards encouraging Netflix, Amazon Prime and others to invest in buying or producing European content. However, as now worded, there is a danger that the provisions for allowing states to impose levies could negatively affect investment by broadcasters.

To address the YouTube challenge, the Commission proposed an extension of the scope of the AVMSD to VSPs, a new category that is now defined as services that are for the dissemination of programmes or user-generated content over which they do not have editorial responsibility, but do have responsibility stemming from their organisation of that content. ${ }^{78}$ Recital 3a, which was added in the final adopted version, explains, "these

2016/0151(COD))' (2018) <http://www.europarl.europa.eu/sides/getDoc.do?pubRef=//EP//TEXT+TA+P8-TA-2018-0364+0+DOC+XML+V0//EN>.

${ }^{77}$ Aside from news content, public and private broadcasters invest overwhelmingly more in fiction that VOD services. Gilles Fontaine, 'TV fiction production in the European Union' $(E A O, 2017)<$ https://rm.coe.int/tv-fiction-production-in-the-eu-2017/16807bb1c2>.

${ }^{78}$ The European Parliament and the Council of the European Union, 'Position of the European Parliament adopted at first reading on 2 October 2018 with a view to the adoption of Directive (EU) 2018/... of the European Parliament and of the Council amending Directive 2010/13/EU on the coordination of certain provisions laid down by law, regulation or ad- 
social media services need to be included because they compete for the same audiences and revenues as the audiovisual media services."79 This addition directly acknowledges the commercial threat to European audiovisual media services posed by the spread of YouTube and other VSPs. The Commission's draft would have required VSPs to protect minors from harmful content and protect all consumers from incitement and illegal content in a similar manner to other audiovisual media services and its proposal relaxed slightly the quantitative advertising limits for linear services and switched product placement rules for audiovisual media services from a "banned except in"... rule to an "allowed except in" one. ${ }^{80}$

The final version of the AVMSD revision goes further towards evening out the rules by applying the rules for commercial communications also to VSPs. Article 9, which itself has been expanded in the revision, sets out common standards for commercial communication. Audiovisual media service providers have been following these rules since the first Directive in 1989, and since the 2007 revision that resulted in the AVMSD they have also participated in codes of conduct related to the advertising of unhealthy food and beverages around children's programming. The novelty in Article 9 is that member states are now required to encourage the use of co-regulation and fostering of self-regulation both for the advertising of alcohol and the codes of conduct on advertising of unhealthy

ministrative action in Member States concerning the provision of audiovisual media services (Audiovisual Media Services Directive) in view of changing market realities' (Euro-

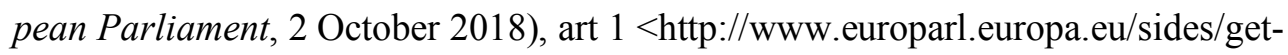
Doc.do?pubRef=-//EP//TEXT+TA+P8-TA-2018-0364+0+DOC+XML+V0//EN> (hereafter: 'AVMSD 2018 adopted text').

${ }^{79}$ ibid.

${ }^{80}$ AVMSD Proposal (n 26). 
food and beverage that "shall aim to effectively reduce the exposure of children to audiovisual commercial communications for such foods and beverages." ${ }^{81}$ The stronger language referring to co- and self-regulation in Article 9 is backed up by another novelty, the addition of an Article 4a, which establishes criteria for such mechanisms including that they: "provide for regular, transparent and independent monitoring and evaluation of the achievement of the objectives aimed at; and provide for effective enforcement including effective and proportionate sanctions." $" 82$

In most of Europe, co-regulatory mechanisms involve advertisers and agencies, and ads are pre-cleared before they appear on television or in print. Advertisements from major advertisers that appear on VSPs will have already passed through this process. Large VSPs, such as YouTube, already have terms and conditions that reflect some of the rules contained in Article 9. However, not all of them are covered, and reducing exposure of children to commercial communication pitching unhealthy food and beverage is a somewhat vague goal that will be difficult to achieve across the volume of content on VSPs. A large portion of online advertising is done by smaller businesses and online-only businesses that do not engage in other forms of advertising. The extent to which these rules will now capture advertising that is not already covered by existing mechanisms will have to be seen and will likely vary by jurisdiction. It is important to note that the revised Directive does make VSPs responsible both for the advertising inventory they sell directly, often through programmatic means, and for the advertising their users are selling on their 'channels' through partnership agreements with the VSPs. ${ }^{83}$ To some extent they may be able to come in line with the Directive by adjusting the terms and conditions to

\footnotetext{
${ }^{81}$ AVMSD 2018 adopted text (n 78) art 9(4).

${ }^{82}$ ibid, art. $4 \mathrm{a}(1)$.

${ }^{83}$ ibid, art $28 \mathrm{~b}$.
} 
which those posting content and selling advertising must comply, but much will depend on the shape and conditions of the national co- and self-regulatory mechanisms. The fact that Article 9 now applies to VSPs as well as audiovisual media services does make the rules fairer in terms of what kind of advertising is allowed and is likely make things somewhat more level in terms of the regulatory burden.

A new rule in the final version of the AVMSD stems from the General Data Protection Rules (GDPR) that went into effect in May 2018, and applies equally to all audiovisual media services and to VSPs. It implements the pronouncement in recital 38 of the GDPR that the personal data of minors deserves special protection particularly in its use "for the purposes of marketing or creating personality or user profiles." ${ }^{84}$ In the recitals of the revised AVMSD, policymakers recognised that the various mechanisms to protect minors, such as age verification and parental controls, will also gather data about them. The AVMSD will now ban audiovisual media service providers (article 6a) and VSPs (article 28b (3)) from using the data gathered for marketing, profiling or targeted advertising. There will be variety in the measures used to protect minors and nature and extent of data gathered across the different services. Even in places where addressable television advertising is being offered, data is mainly about households rather than individual minors, so drawing the line as to what constitutes a minor's personal data will present a challenge. VSPs gather a lot of data about individual users who may be minors, but not all of it might be directly connected to the measures aimed at protecting them, so to what extent will that data be allowed? The details of how this will be implemented will need

\footnotetext{
${ }^{84}$ Regulation (EU) 2016/679 of the European Parliament and of the Council of 27 April 2016 on the protection of natural persons with regard to the processing of personal data and on the free movement of such data, and repealing Directive 95/46/EC (General Data Protection Regulation) [2016] OJ L 119/1, recital 38.
} 
to be carefully worked out in guidance from the Commission and regulators, and probably through future case law. Nevertheless, the rule is the same for both audiovisual media services and VSPs, and is likely to affect VSPs more as their advertising is much dependent on the use of data about individuals.

Rules for commercial communication are still not entirely the same, as linear services still have quantitative limits on advertising, and product placement rules are slightly more relaxed on VOD services, but they are similar, particularly the ones that limit the kinds of advertising services can accept and the special protections for minors. The drafters have taken great care to define jurisdiction in a manner that will capture Google (YouTube), Facebook and other major US-based VSP companies in at least one member state. ${ }^{85}$ No changes to the AVMSD can do much to address the great imbalance between audiovisual media services and VSPs in their access to the kind of data, with consent, required for targeted advertising and the extent of their inventory. Because of this, it is not possible for the Directive to really level the playing field. Nevertheless, it has created more even treatment in terms of key rules affecting revenues and financial obligations, which may help European audiovisual media services be more competitive. The extent to which it protects them will depend significantly on how member states implement the provisions that allow them to impose contributions to funds for content production, and how they set up co-regulatory systems that will encompass the VSPs in the enforcement of advertising rules.

\footnotetext{
${ }^{85}$ AVMSD 2018 adopted text (n 78) art 28b gives member states jurisdiction over a VSP via its parent company, or subsidiary or is part of its group is based there.
} 


\section{Another right for press publishers}

Unlike audiovisual media services, the press has never been the subject of sectoral regulation at the EU level. Similar to online services until the AVMSD revision, the press does not face restrictions on content or advertising beyond general laws related to hate speech, libel and defamation. The Commission identified that the press publishers' loss of revenue was attributable to their lack of bargaining power in relation to online services, and their inability to enforce their exclusive rights online. ${ }^{86}$ Rather than trying to intervene in the conditions of competition for advertising, as the AVMSD does, or the funds available to invest in publishers' content, the Commission has attempted to tackle the intermediary function of the platforms in the distribution of press publishers' content, by adding a property right that can be exercised by publishers. The draft of the proposed new Copyright Directive includes a provision that creates a new layer of neighbouring rights over press publications online $\mathrm{e}^{87}$ that was initially proposed for a period of twenty years, but then reduced to 2 years in the compromised text following the Trialogue, ${ }^{88}$ and which overlays the already existing rights in the publication. ${ }^{89}$ This section explains this attempt

${ }^{86}$ Some academics link this proposal to two recent decisions by the CJEU in Case C572/13 Hewlett-Packard Belgium SPRL v Reprobel SCR [2015] EU:C:2015:750 and the Bundesgerichtshof (German Federal Court of Justice for Civil Matters) in Verlegeranteil, BGH GRUR 2016, 596. See Martin Kretschmer, Séverine Dusollier, Christiphe Geiger and P. Bernt Hugenholtz, 'The European Commission's public consultation on the role of publishers in the copyright value chain: a response by the European Copyright Society' (2016) 38 (10) EIPR 591.

${ }^{87}$ Article 11(1) of the compromised Copyright Directive (n2).

${ }^{88}$ Article 11(4) of the compromised Copyright Directive (n2)..

${ }^{89}$ Compromised Copyright Directive (n 2). Further supported by European Commission, 'Commission Staff Working Document Impact Assessment on the modernisation of EU copyright rules Part 1/3' SWD (2016) 301 final and European Commission, 'Commission Staff 
to change the balance of power and protect Europe's news content production by introducing a new right, and why it is highly problematic and may backfire.

In the print press industry, copyright has never played the central role that it currently does in other content industries..$^{90}$ This does not mean that copyright pays no role whatsoever, but generally to recoup the investment in producing the physical paper and news within it, newspapers have sold advertising space within their pages. ${ }^{91}$ Their model relies on making their content accessible to subscribers, and to physical and online customers, so as to achieve the highest reach possible, thereby being attractive for advertisers. They do not typically deal in the sale or licensing of their content to others, and most have adapted to the spread of the internet by making all or some of their copyright-protected content freely available online on their own advertising-supported sites.

The online environment is characterised by the use of linking and other technologies that enable the aggregation and display of snippets of copyright-protected content. As such, these activities may constitute acts of reproduction, making available to the public and communication to the public which require the right-holder's authorisation to avoid copyright infringement. The likelihood of these activities resulting into a copyright infringement is increased as copyright can be granted in short works including headlines and snippets as long as these meet the originality threshold. ${ }^{92}$ Nevertheless some of these

Working Document Impact Assessment on the modernisation of EU copyright rules Part 3/3' SWD (2016) 301 final.

${ }^{90}$ It remains key to remuneration in the music, and audiovisual industries.

${ }^{91}$ In 1836, French newspaper 'La Presse' is supposed to be the first newspaper to include paid advertising. See for further detail: Dominique Kalifa, 'The Press' in Edward Berenson et al. (eds), The French Republic: History, Value, Debates (Cornell University Press 2011) $192,193$.

${ }^{92}$ Case C-5/08 Infopaq International A/S v Danske Dagblades Forening [2009] EU:C:2009:465, where 11-word extracts were deemed as copyright infringement. 
activities may be rendered permissible through the interplay of the quotation exception. ${ }^{93}$ There are inherent difficulties in invoking this traditional exception in relation to these online uses because exceptions can only be used as a defence. Firstly, the quotation must relate to a copyright-protected work which has already been made lawfully available to the public. Secondly, the use must be in accordance to fair practice or national legal requirements, which leads to a varied scope in different jurisdictions. Finally, the quotation exception has traditionally been conceived as involving some form of comment on the copyright-protected work reproduced. Therefore, an automated activity whereby an algorithm 'crawls', collects, reproduces and communicates to the public excerpts of copyright-protected content is unlikely to be covered by this exception. Based on the above, press publishers already hold a strong position under copyright law.

Despite the fact that the business model of the press industry is not centred on licensing and that publishers already have a legal basis upon which to address the issue of reproduction of their content by online platforms, the Commission identified that: "press publishers are facing difficulties in licensing their publications online and obtaining a fair share of the value they generate" with consequences for their sustainability and ultimately citizens' access to information. ${ }^{94}$ Its proposal to change the Copyright Directive stated that licensing and enforcement of copyright for press publishers was made "complex and inefficient" by a lack of recognition for them as rights holders. ${ }^{95}$ Article 11 of the proposal specifically extends Article 2 of the Copyright Directive, which currently

\footnotetext{
${ }^{93}$ Berne Convention for the Protection of Literary and Artistic Works 1886 (as amended on 28

September 1979) (hereafter: 'Berne Convention'); Directive 2001/29/EC (n 2) art. 5(3)(d).

${ }^{94}$ Compromised Copyright Directive (n 2) p 3.

${ }^{95}$ ibid, recital 31.
} 
lists authors, performers, phonogram producers, film producers and broadcasters as having exclusive reproduction rights, to press publishers. The Article also extends to publishers the rights to authorise or prohibit making their works available to the public. ${ }^{96}$ The move builds upon two national initiatives from Germany and Spain, ${ }^{97}$ and has proven extremely controversial. ${ }^{98}$

Primarily, it is unlikely that the introduction of a new ancillary right will preserve media pluralism as presumed in the Commission's proposal. This new right is more likely to have an adverse effect on media pluralism given that sharing news online would be subject to an additional license and/or fee as demonstrated in the Spanish and German cases. ${ }^{99}$ Here, news aggregators (like Google) decided to stop providing access to these newspapers' content altogether. Therefore, in addition to a negative impact on the accessibility of news online, in the Spanish and German cases the initiatives led to a decline in referrals to these newspapers' websites. In turn, this decreased advertising revenues, an effect that was mostly felt by smaller news publishers. ${ }^{100}$ It would essentially exacerbate the problem identified earlier, of people not going directly to press publishers' websites,

${ }^{96}$ These rights are in art 3(2) of Directive 2001/29/EC.

${ }^{97}$ For more on national initiatives, see Rupprecht Podszun, 'Searching the future of newspapers: with a little help from Google and IP law?' (2013) 44 (3) IIC 259; Rosati (n 14).

${ }^{98}$ Study for the JURI Committee, 'Strengthening the position of press publishers and authors and performers in the Copyright Directive' (2017), p $17<\mathrm{http}$ ://www.europarl.europa.eu/RegData/etudes/STUD/2017/596810/IPOL_STU(2017)596810_EN.pdf>.

${ }^{99}$ Sections $87 \mathrm{f}-\mathrm{h}$ of the German Copyright Law $(U r h G)$ and art. 32(2) of the Spanish Law on Intellectual Property.

${ }^{100}$ The Impact Assessment itself acknowledges the limited effects of this new right in Germany and Spain. Characterising the right of 'ineffective' partly due to 'the lack of scale of national solutions'. At this moment in time, it is still doubtful that a cross-border effect will prove to be more efficient. 
rather than alleviate it. Secondly, there is justified scepticism surrounding the necessity of such ancillary right. Looking at industry practices, employed and freelance journalists rarely remain the owner of the copyright protection vested in their work as these economic rights are generally transferred to publishers. ${ }^{101}$ If the publishers already hold these rights and their enforcement of these rights is the issue, how will adding a layer of rights solve this problem? The approach being taken with Copyright Directive would attempt to intervene in the relationship between press publishers and platforms, unlike the approach taken in the AVMSD, which equalises to some extent the conditions shaping the relationships that audiovisual media services and VSPs each have with audiences and with advertisers.

The Commission's proposal is very broad in scope, as it would apply to all publications including blog posts, social media and other alike platforms, ${ }^{102}$ and therefore would affect all online users and not just address the use of press content by social media

${ }^{101}$ Indeed, section 11 of the CDPA provides that the first owner of copyright is granted to the employer if the work has been created during the course of employment. Furthermore, freelance journalists generally transfer the ownership of economic rights through contractual agreements as per section 90 CDPA.

${ }^{102}$ Article 2(4) of the proposed directive defines 'press publication' as: 'a fixation of a collection of literary works of a journalistic nature, which may also comprise other works or subjectmatter and constitutes an individual item within a periodical or regularly-updated publication under a single title, such as a newspaper or a general or special interest magazine, having the purpose of providing information related to news or other topics and published in any media under the initiative, editorial responsibility and control of a service provider.' Furthermore, recital 33 specifies that: 'For the purposes of this Directive, it is necessary to define the concept of press publication in a way that embraces only journalistic publications, published by a service provider, periodically or regularly updated in any media, for the purpose of informing or entertaining. Such publications would include, for instance, daily newspapers, weekly or monthly magazines of general or special interest and news websites'. 
news aggregators and search engines. ${ }^{103}$ In the compromised text, this has been tempered as the new press publishers right should not affect private individuals and non-commercial uses and excludes very short extracts as well as hyperlinks. However, arguably, information society service providers (including platforms) are unlikely to be able to benefit from the eclusion for very short extracts. ${ }^{104}$ The new right would add a level of complication also for smaller platforms or media organisations that would have to clear content first, so this move aimed at redistributing revenue from the likes of Google and Facebook could have a much more harmful effect on smaller operations. The result of the introduction of this right could be a distortion of competition in the EU information market and higher barriers to entry into the online news market. Instead of facilitating licensing, this right would add complexity and increase the costs linked to the distribution of copyrightprotected content online. ${ }^{105}$

There are also problems with this approach in relation to its scope, in particular the duration for which content is included and what kind of use exactly is covered. The term of protection of 2-3 years is still much longer than new remains relevant and on the

${ }^{103}$ Critiques have also highlighted the fact that the extremely broad scope of this new right is likely to result in granting copyright protection in subject matter traditionally excluded from copyright protection by international treaties such as facts. See Berne Convention (n 93).

${ }^{104}$ See Recital 34a of the compromised text that includes: 'Taking into account the massive aggregation and use of press publications by information society service providers, it is important that the exclusion of very short extracts should be interpreted in such a way as not to affect the effectiveness of the rights provided for in this Directive'.

${ }^{105}$ Furthermore, copyright remains territorial. Therefore, authors are not granted an EU-wide reproduction right but a reproduction right in each jurisdiction where protection is sought. This fragmentation increases the difficulties in licensing; Bently et al. (n 14). 
agenda. ${ }^{106}$ If the lifespan of a news article can be characterised in days, weeks or months, what is the rationale for granting a right lasting for a long period. Much more consideration of consumer habits, public interest and information rights are needed in these debates about duration. Despite the numerous debates, these questions of duration and scope all remain unanswered at present. ${ }^{107}$ Wheras as the new AVMSD attempts to equalise the conditions under which VSP compete for the attention of audiences by evening out many of the consumer protection measures, the creation of the press publishers right with a time frame of 2-3 years, is likely to actually disadvantage press publishers content in relation to audiences.

The EU Parliament and the EU Council have explored alternatives, one of which is the possibility to introduce a presumption of representation of authors for the sake of rights enforcement. ${ }^{108}$ Drawing on national level initiatives, the idea here is to infer that news publishers have the relevant rights in the copyright-protected content to by-pass the need for publishers to have to establish that they are the owners of the rights for online enforcement. ${ }^{109}$ Such an option would have limited the additional burden to smaller

${ }^{106}$ Christophe Geiger et al., 'Opinion of the Centre for International Intellectual Property Studies (CEIPI) at the University of Strasbourg on the European Commission's copyright reform proposal, with a focus on the introduction of neighbouring rights for press publishers in EU law' (2016) CEIPI Research Paper No. 2016-01 <https://papers.ssrn.com/sol3/papers.cfm?abstract_id=2921334\#\#>. It was sent to the European Commission on 2 December 2016.

${ }^{107}$ Frosio et al. (n 14) 208-209.

${ }^{108}$ European Parliament Committee on Legal Affairs, 'Draft Report on the proposal for a directive of the European Parliament and of the Council on copyright in the Digital Single Market (COM(2016)0593 - C8-0383/2016 - 2016/0280(COD))' (2016) 2016/0280 COD (limiting the new right to 1 year since publication); such proposal is presumably based on a strengthening of article 5 of Directive 2004/48/EC.

${ }^{109}$ Study for the JURI Committee (n 98) 15. 
online services and new entrants, but it is also not likely to help press publishers to secure a stronger bargaining position or recoup part of the revenue lost to the digital consumption. ${ }^{110}$ Intervening with the addition of an additional layer of property rights on content holds little promise for addressing the problem of press publishers not getting a "fair share of the value" from their content, while, as several have argued, it could have negative consequences for freedom of expression. ${ }^{111}$

\section{Conclusion}

As it becomes harder for traditional media companies to secure the same amount of advertising income as in the analogue age, the future of advertising-financed content produced by traditional players will be increasingly threatened. ${ }^{12}$ As was the case in the 1980 s, once again the threat is perceived as coming in the form of powerful US based companies that are bigger and better resourced than anything in Europe. These dynamics could be viewed as broader problems, and threats global platforms pose to traditional media in the US have also been recognised by scholars and industry monitors there. ${ }^{113}$

\footnotetext{
${ }^{110}$ The Impact Assessment acknowledges this too.

${ }^{111}$ Is there a pressing social need justifying the introduction of this right and therefore, the curtailing of the right to freedom of expression? Here, scholars have expressed criticisms. van Eechoud (n 14) 18-24; Study for the Juri Committee (n 98) 24; Pihlajarinne and Vesala (n 14) $220-228$.

${ }^{112}$ ibid.

${ }^{113}$ For a study examining the impact of social media platforms and technology companies on the sustainability of 'traditional press publishers', see: Emily Bell et al., 'The Platform Press - How Silicon Valley Reengineered Journalism' (Tow Center for Digital Journalism at Columbia Journalism School, 2017) <https://doi.org/10.7916/D8R216ZZ>. See also: Nushin Rashidian et al., 'Friend and Foe: The Platform Press at the Heart of Journalism' (Columbia Journalism Review, 2018) < https://www.cjr.org/tow_center_reports/the-platform-press-at-the-heart-of-journalism.php/> .
} 
However in the context of EU policy process, they have been framed as about the health of European content production and even European culture. The approaches being taken in the AVMSD and the Copyright Directive to deal with these threats are very different. The new AVMSD continues with trying to establish fair common rules for competition and imposing obligations to invest in content production. It has been revised with the intention of 'levelling up' the common standards for audiovisual media services, applying most of them to the online VOD services and VSPs. Policymakers have sought to redress the imbalance in the market for advertising budgets by extending the limitations audiovisual media services face to these US based companies. ${ }^{114}$ It essentially intervenes in the relationship between VSPs and advertisers in an attempt to approximate it to that between audiovisual media services and advertisers, while getting closer to matching the obligations on those carrying professionally produced content (as opposed to user-generated content) to contribute to the production of European content. Though as noted above there are uncertainties and even dangers in how the final revision has been worded in relation to the potential for states to impose levies and the flexibility of co-regulation, there is more potential for the AVMSD to go some way towards ensuring revenues for traditional content producers than would the proposed changes to the Copyright Directive.

The compromised text of the Copyright Directive would add a press publishers right with the hope that this will facilitate the licensing of EU works online and bring additional revenues to press publishers. It would intervene in the relationship between press publishers and the various online platforms, mainly US-based companies rather than in the relationships through which press publishers currently derive revenues. It will not affect the rules of the game in which the press publishers and platforms compete for

\footnotetext{
${ }^{114}$ Except for the quantitative rules, which still apply only to linear services.
} 
advertising revenue, nor will it create new obligations for platforms to invest in content. The extra layer of intended protection for press publishers is not matched by incentives for the platforms to carry press publishers content, and given the existing imbalance of power, it is likely to have an effect opposite that which is intended. In fact, the press publishers already have rights that could be relied upon to serve that function, and these have not worked, so there is little reason to expect a new right would.

Fundamentally behind the strength of advertising dependent online platforms is the data they hold on their users and their nearly limitless advertising inventory. No provisions in the AVMSD or the introduction of a press publisher's right will rectify this. A closer look at the 'walled gardens' of user data and measurement metrics might identify places where other interventions might be applied to redress some of the imbalance. If European policymakers want to improve and protect the share of their content's value that press publishers are receiving, they should examine the trading practices of programmatic advertising and the levels of concentration within that ecosystem. Using a levelling approach similar to that taken in the AVMSD, in relation to transparency, taxation, and data, or perhaps applying competition or commercial practices rules, might do much more to help press publishers recoup some of their position in advertising markets.

The different nature of the viewer experience and the continued recognition of some long-term effects of long form, mass advertising (i.e. on TV) means that audiovisual media services are not as threatened as press publishers. They are also adapting by launching more targeted and interactive options, and the companies behind them are themselves getting into the game of adtech, diversifying their holdings in attempts to match the concentration along the value chain that the large US players such as Google already have. Press publishers are also trying to adapt, but it may be that advertising revenue streams for press publishers will dry up, or at least no longer be able to provide sufficient funding 
to support the kind of content needed. In the tradition of supporting the use of state aid for press publishing there may need to be more funds for supporting press content, ${ }^{115}$ particularly news, in the model of the funds for supporting audiovisual content, perhaps like the EU level Creative Europe programme or even involving levies on platforms like those now allowed by the AVMSD. There could be forms of quotas for European news content that could be imposed on aggregators or other platforms coupled with obligations to contribute in a manner similar to those the AVMSD contains for VOD services. In order to protect European content production in the face of global online platforms, European policymakers will need to pay close attention to how the AVMSD is implemented, offering the right guidance as to which platforms count as VSP and how co-regulatory regimes are shaped. At the same time, should the press publisher's right fail to have the effect of increasing revenues for press publishers, which seems likely, they should look towards the protectionist measures that have been long used in the audiovisual arena for options.

\section{Acknowledgement}

All websites last accessed 30 January 2019.

${ }^{115}$ For example, the 'Cairncross Review' in the UK, which is looking at how to sustain the production and distribution of high-quality journalism has consulted on the option of some kind of subsidy. For further detail see The Cairncross Review, 'A sustainable future for journalism' (HM Government, 12 February 2019) <https://assets.publishing.service.gov.uk/government/uploads/system/uploads/attachment_data/file/779882/021919_DCMS_Cairncross_Review_.pdf\$ 